\title{
The Antecedents of Mobile Repurchasing Intentions: An Empirical Investigation among Turkish Mobile Shoppers
}

\author{
Mutlu Yüksel Avcılar ${ }^{1} \&$ Akın Alkevli $^{2}$ \\ ${ }^{1}$ Department of Management Information Systems, Faculty of Economics and Administrative Sciences, \\ Osmaniye, Osmaniye Korkut Ata University, Turkey \\ ${ }^{2}$ Department of Business Administration, Institute of Social Sciences, Osmaniye, Osmaniye Korkut Ata \\ University, Turkey. \\ Correspondence: Mutlu Yüksel AVCILAR, Department of Management Information Systems, Osmaniye Korkut \\ Ata University, 80000 Osmaniye, Turkey. E-mail: myukselavcilar@osmaniye.edu.tr
}

Received: January 20, 2017

Accepted: February 10, 2017 Online Published: February 22, 2017

doi:10.5539/ijbm.v12n3p105

URL: https://doi.org/10.5539/ijbm.v12n3p105

\begin{abstract}
In today's digital world, consumers have progressively utilized the mobile Internet in their mobile shopping transactions. Mobile retailers are forcing themselves to impact consumers' mobile shopping attitude and behavior by generating new shopping experiences on the purpose of their business life cycle under the threat of destructive competitive factors between retailers operating both in conventional and online stores. Considering the destructive competitive business conditions, it is crucial for mobile retailers to understand mobile shoppers' beliefs, attitudes mobile shopping intentions, and behavior related to mobile shopping. Thus, the aim of this research is to examine an extended Technology Acceptance Model (TAM), Consumer Perceived Value and Flow theory that will ensure eloquent comprehension of making purchases via mobile devices. Indeed, utilitarian and hedonic value, perceived enjoyment and flow dimensions are added into the research model.

In data collection phase, convenience sampling method was used and face-to-face interviews methods were exercised. The 400 valid questionnaires were collected from the mobile shoppers who willingly participate with our research in Adana, Turkey. In order to test the research model, we used Partial Least Squares (PLS-PM) analysis method. The study results enable significant support for the proposed research model. Analysis result reveals that perceived ease of use, perceived usefulness, perceived enjoyment, mobile shopping flow experience, mobile shopping attitude, mobile shopping satisfaction, perceived utilitarian value, and hedonic value dimensions positively affect mobile repurchase intentions.
\end{abstract}

Keywords: mobile shopping, mobile shopping enjoyment, flow experience, mobile shopping repurchase intention, mobile shopping satisfaction, perceived mobile shopping utilitarian and hedonic value, technology acceptance model.

\section{Introduction}

A smartphone is a mobile phone with an advanced mobile operating system that combines features of a personal computer operating system with other features useful for mobile or handheld use. Furthermore, a smartphone can access the Internet and can run a variety of applications. Therefore, today's consumers view smartphones not just as a device for calling and texting, but as a multi-use device for gaming, socializing, and downloading apps, browsing, and purchasing product and services.

In recent years, global mobile shopping and m-commerce have been a growing phenomenon. According to Statista (2016), worldwide mobile commerce revenues amounted to 171 billion U.S. dollars in 2016 and expected to grow 693 billion U.S. dollars in 2019. Today, global mobile commerce is $34 \%$ of all e-commerce transactions and is predicted to grow 31\% while e-commerce expected to grow at $15 \%$ in 2017 (Statista, 2016). A conducted study concerning with mobile shopping penetration across the globe in 2015, global survey results indicated that $46 \%$ of internet users in Asia Pacific region and $20 \%$ of those in North America had made purchasing using any mobile device such as smartphone or tablets (Statista, 2016).

In addition, according to the results of the household information technologies usage survey in Turkey, published by the Turkish Statistical Institute in 2016, the rate of the Internet use in the 16-74 age groups is 61.2 percent and 
the number of people connected to the internet via smartphone is approximately 41.5 million people. In terms of internet usage purposes, $82.4 \%$ of individuals reported that they used the internet for participating in social networks, and $65.5 \%$ of individuals mentioned that they used the internet for finding information about goods and services. Moreover, the percentage of ordering or buying goods or services over the Internet for private purposes was only 34 percent in Turkey. Although people use smartphones intensively in terms of entertainment, communication, information searching and sharing, and comparing prices, however, purchasing levels remain at a low level. These statistics indicate us that as an emerging phenomenon mobile shopping via smartphone has not adopted extensively between smartphone users.

Mobile technology and mobile Internet services have been spreading expeditiously in the global world. The implementation of third-generation $(3 \mathrm{G})$ techniques of mobile communication has encouraged the m-shopping enhancement (Zhou, 2013). With the fast advancement of the Internet and particularly mobile Internet, shopping transforms excessively elastic in the sense of time, space (Balasubramanian, Peterson, \& Jarvenpaa, 2002), and channels (Kalyanam \& Tsay, 2013). Mobile devices have numerous key features like mobility, location-specificity, and ubiquitousness that persuade customers to make use of these devices with wide range of shopping operations: making a shopping list, searching, pondering, comparing, purchasing, and post-purchasing operations (Shankar \& Balasubramanian, 2009). Ever since mobile technology has been inserted nearly each perspective of customer's routine life cycle, mobile shopping has turned into an option for them to search, browse, compare and purchase goods and services in online platforms from several suppliers or retailers at any given time in case of customers own mobile devices (Holmes et al., 2013; Lu \& Su 2009; Yang \& Kim 2012). In the history of m-shopping, Fenech (2002), Jih and Lee (2003) have stated that it is not recent notion and has been come into being for a little over 10 years. The real milestone came into the light related with the put onto the global market is developed mobile devices like smartphones (Scoop Media, 2013; Nielsen, 2013).

Shankar et al. (2010) suggested that mobile devices, particular, smartphones will embody the development of retailing realm. In addition, they will depict undiscovered service borderline (Kleijnen et al., 2007). Verkasalo et al. (2010) stated that customers should adopt mobile device usage to receive support about a diversity of circumstances in the flow of life, involving purchasing environment. By means of mobile devices, the mobile data flow emancipates users from inhibitive factors such as time and location and provides them to make a purchase with no restrictions. This situation enables comfort to individuals and encourages them to boost habitual activities via mobile devices (Zhou, 2016). However, customers may feel obliged to use mobile devices only for shopping without feeling any optimal and pleasurable experiences related to reward and enjoy in itself (Guo \& Poole, 2009). Data from several sources have identified the term of flow as an optimum status of experience, has been discovered to have a positive relationship with explanatory behavior, intentions of revisit, purchase, and attitude towards websites (Novak et al., 2000; Skadberg \& Kimmel, 2004; Guo \& Poole, 2009).

In order to identify the determinants having an impact on the intention to make purchases via mobile devices, the chosen model is Technology Acceptance Model (Davis, 1989) to which has been attached with external variables such as perceived enjoyment, flow experience, perceived hedonic value and utilitarian value. Technology acceptance model is regarded as efficacious evaluation model in the research of determinants concerning about the usage of information technology, by virtue of substantiality, elasticity, explicative power (Arning \& Ziefle, 2007; Djamasbi et al., 2010; Li \& Bai, 2011). Based on this model, product usage is related to intention to use (IU), which is linked to the attitude towards intention. The attitude is shaped by consideration of the perceived ease of use (PEOU) and perceived usefulness (PU). In mobile technology, Wu et al. (2011) have suggested that including attitude variable clarifies the intention to use mobile technology. Consistent with this study, in terms of model's evidence, attitude dimension has been included in the technology acceptance model.

There is a large volume of published studies describing the role of technology adoption theories like technology acceptance model (TAM) (Shin et al., 2010), innovation diffusion theory (IDT) (Mallat, 2007), task-technology fit (TTF) (Yuan et al., 2010) and the unified theory of acceptance and use of technology (UTAUT) (Park et al., 2007) to evaluate users behavior in mobile environments. The empirical findings in these studies provide that the perceived usefulness, relative advantage, task-technology fit and performance expectancy are suggested to have an impact on user adoption of mobile services. Recent studies involved to determine the factors having an impact on users adoption of m-shopping (Ko et al., 2009; Lu \& Su, 2009; Zhou, 2013). The evidence such as perceived value and perceived usefulness have an effect on mobile shopping intention. Liu et al. (2011) identify mobile user loyalty in terms of relationship qualities and switching barriers. However, these factors are basic beliefs refer to extrinsic motivational components. Zhou (2013) draws our attention to the impact of intrinsic motivations related to the behavior of mobile users has rarely been examined. Davis et al. (1992) have found that intrinsic motivation has an important impact on user's behavior. Therefore, it is needed to evaluate intrinsic and 
extrinsic motivational factors to clarify behavior on mobile shopping. Such that mobile users may not merely anticipate for product or service quality besides anticipate for achieving a better experience (Zhou, 2013). In this study, we evaluated motivations with the flow experience, which refer to an optimal experience while making purchases via mobile devices. In line with this research, our study also based on extended technology acceptance model and flow theory components to evaluate mobile user purchase intention via mobile shopping. Still, users' flow state and perceived value in mobile shopping have rarely examined.

Comparative to increasing significance of mobile shopping, from an academic perspective, very little is known about the mobile shopping flow experience, hedonic and utilitarian values about mobile shopping, and in particular, in terms of smartphones. There is a requirement for an advanced comprehension of which factors impact flow state and perceived value of customers owning smartphones while mobile shopping. To our best knowledge, this study is the first attempt to identify the factors affecting the propensity of customers to shop via mobile devices from the viewpoint of Technology Acceptance Model, Perceived Value and grounded Theory of the Flow. In other words, the purpose of this study is to determine the antecedents of propensity to m-shopping re-purchase intentions.

Therefore, our study has been organized in the following way. We propose the research model and hypotheses in section 2. Section 3 determines the instrument development and data collection method. The results are presented in section 4. Section 5 includes a discussion of these results. Section 6 concludes the implications and limitations of this study.

\section{Theoretical Framework and Hypotheses}

Mobile shopping as a new technology has drawn scholars' attention. In these studies, IT theories like Technology Acceptance Model (Davis, 1989) which is based upon Theory of Reasoned Action/TRA (Fishbein \& Ajzen, 1975) is frequently taken part as a theoretical review. Lu and $\mathrm{Su}(2009)$ found that enjoyment, usefulness, compatibility, and anxiety have an impact on mobile shopping intention. Ko et al. (2009) stated that usefulness, enjoyment, instant connectivity and ease of use are significant determinants of perceived value that has an impact on adoption intention of mobile shopping. Zhou (2013) revealed that trust, flow, and perceived usefulness are estimators of mobile purchase intention and contextual offering has significant effects on trust, flow, and perceived usefulness. Lai et al. (2012) found that initiators like trust, privacy, and security are significant determinants of starting to use mobile shopping. Kim and Kang (2001) have suggested that in terms of smart shopping, present over busy customers may look for hedonic benefits together with utilitarian aspects. Green et al., (2012) described smart shopping as "consumers seeking to minimize the expenditure of time, money, or energy to gain hedonic or utilitarian value from the experience" (Green Atkins \& Kim, 2012, 361). Devaraj et al. (2003) suggest that satisfaction is a significant estimator of intention continuance. According to Wang and Liao (2008), mobile users having more satisfaction are anticipated to be intended for re-purchasing.

As it has seen in terms of these studies, although mobile shopping and mobile shopping intention has drawn attention from scholars flow, hedonic and utilitarian values have rarely been examined. This study tries to fill this gap by including flow dimensions and other external variables.

\subsection{Perceived Ease of Use}

Perceived ease of use has been defined as "the degree to which a person believes that using a particular system would be free of effort." This leads to the description of the word ease: "freedom from difficulty or effort". Effort can be defined as a limited source that an individual may share out to the numerous operations for his or her liabilities (Davis, 1989). Venkatesh and Davis (1996) have defined perceived ease of use: "perception of the effort level needed to complete a transaction by the individual when using a system". Davis (1989) has claimed that under fixed conditions, an implementation comprehended for using easily compared to others, is more supposedly to be adopted by users. Budzanowska-Drzewiecka (2015) has suggested that perceived ease of use reflects the users' sensations characterizing the effort achieving technological solutions. The most striking result from the various empirical studies found that perceived ease of use has a positive effect on behavioral intention (Davis, 1989; Gefen \& Straub, 1997, 2000; Venkatesh \& Davis, 2000; Gefen, 2003). Agarwal and Karahanna (2000) have demonstrated that ease of use as the main determinant of intention to adopt. Several scholars have found that this notion suggesting an effect of mediating. Igbaria et al. (1995) suggested that perceived ease of use has an indirect mediating effect on perceived usefulness. Perceived ease of use can be asserted as one of the dominant behavioral components affecting users' intention to TAM in terms of both original and revised Technology Acceptance Model (Bhatti, 2007). Therefore, there is enough evidence to suggest the following hypotheses:

Hypothesis H1.Perceived ease of use has a positive effect on perceived usefulness. 
Hypothesis H2. Perceived ease of use has a positive effect on mobile shopping attitude.

\subsection{Perceived Usefulness}

The perceived usefulness described as "the degree to which a person believes that using a particular system would enhance his or her job performance" (Davis, 1989). It referred in the literature as the perception of persons with respect to enhancement of the duties fulfilled while accessing the system. The results empirically reveal that the concept of perceived usefulness is the basic estimator of intention to use any system (Davis, 1989; Gefen \& Straub, 2003; Hsu \&Lu, 2004). This leads to the description of the word useful: "capable of being used advantageously." In terms of organizational context, individuals are usually promoted for better performance by raises, promotions, bonuses, and other rewards. Any system having a higher perceived usefulness, thus it is unique for any user considers the presence of a positive use-performance relationship (Davis, 1989).

This result was emphasized in terms of m-commerce (Wu \& Wang, 2005). Perceived usefulness has been determined to be a variable estimating basic adoption and post adoption (Shin et al., 2010). Zhou (2013) revealed that perceived usefulness estimates mobile purchase intention. Perceived usefulness has found to be a hegemonic factor that has an impact on online purchase intention (Sin et al., 2012). There is a large volume of published studies describing the significant effect of perceived usefulness on usage intention (Davis, 1989; Venkatesh \& Morris, 2000). A person estimates the results of the behaviors regarding perceived usefulness and ground on their preference of the behavior according to the demand of perceived usefulness. Thus, perceived usefulness will affect the intention to internalize the mobile commerce (Bhatti, 2007). Various studies have revealed that the perceived usefulness is the basic estimator of IT usage (Davis, 1989; Davis et al., 1992; Igbaria et al., 1997; Gefen \& Straub, 1997, 2000; Venkatesh, 2000; Venkatesh \& Davis, 2000; Gefen, 2003; Hsu \& Lu, 2004). Bhatti (2007) has stated that m-commerce is the expansion of e-commerce; therefore it is excusable to extend Technology Acceptance Model to investigate users' intention to adopt behavior. Consistent with the studies, we propose:

Hypothesis H3: Perceived usefulness has a positive effect on mobile shopping attitude.

\subsection{Perceived Enjoyment}

Perceived enjoyment refers to: "the degree to which the use of the computer is perceived as pleasant, regardless of all consequences of execution which may be envisaged" (Davis et al., 1992). To the extant literature, exhibiting behaviors by individuals are relatively affected by perceived enjoyment (Teo et al., 1999). Agrebi and Jallais (2015) have suggested that a qualitative study conducted with 26 French users (half of them users and remaining part was nonusers) have asserted that shopping via mobile devices can be felt as pleasant, in addition, time-free and location-free reinforce users to access mobile websites. In this regard, perceived enjoyment is the notion to assert the intention of using mobile devices in order to shop, based on both utilitarian and hedonic factors also in m-shopping context. A recent study by Teo et al. (1999) involved the effects of intrinsic and extrinsic motives in respect of technology usage, centering especially upon the Internet. The authors revealed that perceived ease of use has an effect on perceived enjoyment. Actually, the more ease of the system, the more having fun (Bruner \& Kumar, 2005). Thus, we set forth the following hypotheses:

Hypothesis H4: Perceived enjoyment has a positive effect on mobile shopping flow state.

Hypothesis H5: The perceived enjoyment has a positive effect on mobile shopping attitude.

\subsection{Mobile Shopping Flow Experience}

The Flow was described as a holistic sensation, total concentration, and intrinsic enjoyment (Csíkszentmihályi, 1997; Csíkszentmihályi \& LeFevre, 1989). Flow shows similarities with absorption and top performance, but in fact, it is different from them. Absorption refers to a trait or personal propensity to dedicate himself/herself to paying particular attention to the case (Tellegen \& Atkinson, 1974). Hence, flow can be named as a state but not a trait. Absorption is not obliged to be enjoyable. The mentioned information reflects the differentiation among flow and absorption. By the way, peak performance can be described as a part of stronger operations. Peak performance may partly correspond to flow, however, flow is sole due to holding enjoyment in its description (Privette, 1983).

Hoffman and Novak (1996) described flow as a state that is qualified by a perfect chain of responses enabled by machine interactivity, intrinsic enjoyment, loss of self-consciousness and self-reinforcement. As a wide and complicated concept, flow results from diverse components like perceived enjoyment, perceived control, and concentration (Hoffman \& Novak, 2009). Perceived enjoyment refers to pleasure and enjoyment relevant with accessing mobile stores. Perceived control refers to feelings of control on the task and peripheral factors. Concentration refers to user focusing and involvement while conducting a mobile purchase. By reason of 
important impact related to users' behavior, flow has been analyzed in a wide range of studies like instant messaging (Zaman et al., 2010), e-learning (Ho \& Kuo, 2010), virtual worlds (Animesh et al., 2011), online shopping (Guo \& Poole, 2009) and mobile platforms that involve mobile games (Ha et al., 2007), mobile instant messaging (Zhou \& Lu, 2011) and mobile television (Jung et al., 2009).

In the present study, we focused on the nine dimensions of flow theory. As an autotelic experience refers to "the key element of an optimal experience is that is an end itself." (Csíkszentmihályi, 1990, p. 67), customers may evaluate shopping via mobile internet, as a task is perceived for its own sake. In terms of sense of control, it may be embodied diverse things such as outcomes or how the shopping is progressing (process control) (Keller \& Bless, 2008). In another word, on the process control, that customer may totally feel in control on mobile shopping. Concentration as a dimension of flow experience refers to "a centering of attention on a limited stimulus field" (Csíkszentmihályi, 1975, p. 40). Customers may totally concentrate on mobile shopping transactions via mobile devices. Merging action and awareness refers to "people become so involved in what they are doing that the activity becomes spontaneous, almost automatic; they stop being aware of themselves as separate from the actions they are performing." Customers may consider themselves like robotic devices while using their smartphones for shopping. Transformation of time reflects "distorted sense of time" (Csíkszentmihályi, 1988, p. 33) or "time no longer seems to pass the way it ordinarily does" (Csíkszentmihályi, 1990, p. 66). It may highlight the waste of time while m-shopping either slow or fast motion. Loss of self-consciousness refers to "lose temporarily the awareness of self" (Csíkszentmihályi, 1988, p. 33). This definition may be evaluated in terms of m-shopping such customers may lose their consciousness during the mobile shopping actions. For the occurrence of flow experience; clear goals, unambiguous feedback, and balance of challenge and skills are indispensable elements (Csíkszentmihályi \& Csíkszentmihályi, 1988). Regarding aforementioned $\mathrm{m}$-shopping activities should have definite purposes, indicating the level of performing the $\mathrm{m}$-shopping transactions and balancing the demands of $\mathrm{m}$-shopping activities and perception of users' skills.

To the extant literature, users may focus on mobile shopping activities; feel in control while making mobile purchases; may find a lot of pleasure and love the feeling of that performance and want to try it again. Perceived usefulness has been determined to be a variable estimating basic adoption and post adoption (Shin et al., 2010). Consistent with the studies we propose:

Hypothesis H6: Mobile shopping flow experience has a positive effect on mobile shopping attitude.

\subsection{Mobile Shopping Attitude}

Based on Fishbein and Ajzen's (1975) Theory of Reasoned Action (TRA), Technology Acceptance Model (TAM) proposes that there is a reason-oriented structural relationship among attitude, intention, and behavior (Davis, Bagozzi, \& Warshaw, 1989). This situation has also corroborated by previous studies such as examining the acceptance of a wide range of Internet services (Gillenson \& Sherrell, 2002; Lin, 2008; Moon \& Kim, 2001; Sánchez-Franco \& Roldán, 2006). The elements related to technology (i.e. perceived usefulness and perceived ease of use) has an effect on attitude, attitude reflects any person's predisposition or a tendency to respond positively or negatively relevant to an assessment of a specific behavior (Ajzen \& Madden, 1986; Fishbein \& Ajzen, 1975) which creates the behavior. As a result, reciprocally the more positive assessments of behavior, the more propensities to accept the latest technologies contrary to this, the negative assessments will clearly hinder anyone from accepting latest technologies (Groß, 2015). Many of the research about mobile shopping acceptance have currently validated the relationship between attitude and intention (Aldás-Manzano, Ruiz-Mafe', \& Sanz-Blas, 2009; Kim, Ma, \& Park, 2009; Yang, 2010, 2012). However, they were inadequate to explain the relationship between intention and behavior. Groß (2015) explained the basic reason of this inadequacy concerning with the studies by a favor of including inexperienced users (data collection and sampling) about mobile shopping.

Customers are increasingly utilizing mobile devices for their shopping activities. Holmes et al. (2013) suggest that users having smartphone appreciated the practicality of mobile shopping. Indeed, smartphone awareness may be suggested in terms of m-shopping context due to its advantages for customers while making shopping. As a result, customers may generate favorable attitudes towards mobile shopping. Therefore, there is enough evidence to suggest the following hypotheses:

Hypothesis H7: Mobile shopping attitude has a positive effect on mobile shopping satisfaction.

Hypothesis H8: Mobile shopping attitude has a positive effect on utilitarian mobile shopping value.

Hypothesis H9: Mobile shopping attitude has a positive effect on hedonic mobile shopping value. 


\subsection{Perceived Utilitarian Value}

Utilitarian consumer behavior has been described as task-related and rational (Batra \& Ahtola 1991; Sherry, 1990). Utilitarian value refers to shop associated with working attitude of mind (Holbrook \& Hirschman, 1982). Extended perceived utilitarian value will decrease customer's requirement to search options, however, perceived value is declining, customers will move to another products or services (Anderson \& Srinivasan, 2003; Chang, 2006). To the extant literature, scholars reveal that utilitarian value has a positive effect on a purchase and repurchase intention (Dodds et al., 1991; Parasuraman \& Grewal, 2000; Chiu et al., 2005; Hume, 2008). In the case of a purchasing via mobile devices provides higher utilitarian value. Thus, we offer the hypotheses below:

Hypothesis H10: Utilitarian value has a positive effect on mobile shopping satisfaction.

Hypothesis H11: Utilitarian value has a positive effect on mobile shopping repurchase intention.

\subsection{Perceived Hedonic Value}

There are different and ambiguous descriptions of e-commerce and m-commerce in the extant literature. E-commerce reflects the operations of exchange (sales and purchases) together with customers can obtain information concerning offers in instant time period and purchase goods using online platforms (Li, Dong \& Chen, 2012). M-commerce can be defined as "persuading users to make purchases using mobile devices." Therefore, m-commerce can be regarded as processes made using mobile networks (Okazaki, 2005).

Hedonic value shows subjective and individual features in the matter of fun, playfulness than task fulfillment (Holbrook \& Hirschman, 1982). Therefore, hedonic shopping value refers to the entertainment and emotional level of shopping. In this regard, shopping experiences as perceived itself rewarding separate from tasks. Enhanced stimulations, increased involvement, feeling of freedom, perceived fantasy and escapism totally may point out shopping experience as hedonically valuable (Babin et al., 1994). Moreover, consumption can enable hedonic value by persuading a consumer to derive pleasure from a product's advantages before purchasing (Maclnnis \& Price, 1987). Definitely, perceived enjoyment itself is a significant hedonic advantage enabled via shopping (Bloch et al. 1986). Indeed, shoppers seeking fun are potential individuals who anticipate higher hedonic values (Babin et al., 1994). Consistent with the studies, we propose:

Hypothesis H12: Hedonic value has a positive effect on mobile shopping satisfaction.

Hypothesis H13: Hedonic value has a positive effect on mobile shopping repurchase intention.

\subsection{Mobile Shopping Satisfaction}

Technology acceptance model was widely used to clarify the acceptance of information systems. In terms of m-commerce, the model was used in many studies. All these studies met on a common ground related to their research models, was the perception of customers and/or persons. Satisfaction described as "the summary psychological state resulting when the emotion surrounding disconfirmed expectations is coupled with a consumer's prior feelings about the consumer experience" Oliver (1997); "an attitude construct that affects consumers' behavioral intention" (Devaraj et al., 2002); "perception of pleasurable fulfillment of a service, and loyalty as deep commitment to the service provider" (Shankar et al., 2002, p.2). Agrebi and Jallais (2015) indicated that customer satisfaction can be described as a tendency for the purchases likely which will be made in the future. The aforementioned concept was primarily clarified in job performance context in the way in the study of Locke (1976) that it is an enjoyable and favorable sensual status due to an assessment of anyone's performance (Bhattacherjee, 2001). The description was expanded on the study of Oliver (1981), involving the contextual usage in such a manner that it is as a psychological and/or sensual status due to a cognitive evaluation of the gap among prospects and de facto performance (approval or disapproval) (Wang and Liao, 2008). Satisfaction in the mobile commerce context is the resume of the sensual reaction later on the m-commerce practices and is triggered by various facets (i.e. quality of service, information, and system). Mobile users having more satisfaction are anticipated to be intended for re-purchasing (Wang and Liao, 2008). Indeed, performance gets up with the users' prospects; assessment of post-choice is a favorable tendency for mobile shopping. Thus, customers are more presumably to use or continue to use mobile devices for shopping. Devaraj et al. (2003) suggest that satisfaction is a significant estimator of intention continuance. Thus, the following hypothesis is proposed:

Hypothesis H14: Mobile shopping satisfaction has a positive effect on user's mobile re-purchase intention.

\subsection{Repurchase Intention}

Time-constrained consumers have popularized shopping via mobile devices. The high volume of handheld devices turns the mobile shopping into a new opportunity (Hung et al., 2012). However, some of the consumers 
that have mobile shopping experience are reluctant to shop via mobile devices and this may cause deceleration of the mobile shopping growth rate (Anil et al., 2003). Therefore, it is significant to understand the reliable predictors in the m-shopping context. Purchase intention refers to "a cognitive state reflecting the consumer's plan to buy in a specified time period" (Howard \& Sheth, 1969), likewise, Bigne-Alcaniz et al. (2008) asserted as "mental state that reflects the consumer's decision to acquire a product or service in the immediate future". Repurchase intention defined by Zhang et al. (2011) as "a manifestation of customer loyalty". Despite the literature indicates the various dimensions of loyalty (Harris \& Goode, 2004), from the behavioral viewpoint, repurchase has a significantly direct influence on the vendors' sales volume. Repurchase intention can be described by Hellier et al. (2003) as "a customer's willingness to make another purchase from the same firm, based on previous experiences".

This study was designed to clarify customers' mobile repurchase intention. The foundations of this study are based on the technology acceptance model (TAM) and perceived value and flow theory. Mobile shopping flow experience, perceived usefulness will support user's intention to make mobile purchases. Flow as a shopping experience encourages behavioral intention (Hoffman \& Novak, 2009). In order to determine the factors affecting the propensity of customers to shop via mobile devices, we included in our research model, flow, perceived utilitarian and hedonic value dimensions. Consequently, we examined mobile repurchase intention as an endogenous variable instead of studying mobile customers' actual behavior. In this context, the proposed conceptual research model and hypotheses are shown in Figure 1.

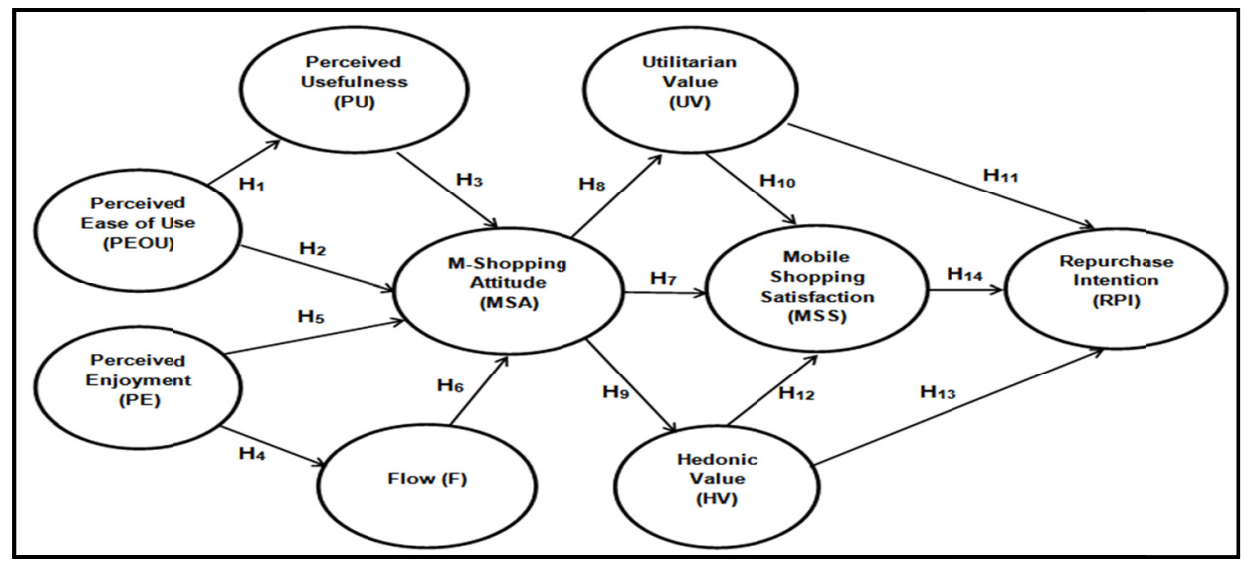

Figure 1. Research Model

\section{Research Methodology}

A survey research was conducted to collect empirical data. During the research process, we used convenience sampling method and face-to-face interviews technique to collect data. The analysis was performed by using Partial Least Squares. The SmartPLS 3.0 software (Ringle et al., 2015) was used to assess the measurement and structural model. The following sections describe sampling and data collection process, questionnaire design and measurement instrument and analysis method.

\subsection{Sampling and Data Collection}

Theoretically, the population of this study consists of the smartphone users who are over 18 years old and who had made a mobile purchase experience in the last six months. Because there does not exist such a list of the mobile shoppers, it is not possible to arrange our sampling frame. Therefore, respondents were selected using a convenience-sampling method at public facilities (university campus, local mall, a few busy boulevards, and public institutions). Before data collection, the survey was analyzed to determine the typographical and punctuation errors by a couple of professor in Turkish Language and Literature department. The 400 valid questionnaires were collected between October and December 2016, via face-to-face interviews with the mobile shoppers in Adana, Turkey.

\subsection{Questionnaire Design and Measures}

The questionnaire for this study consists of two main sections. The first section contains questions directed to the scale items (indicators), selected to measure each construct based on existing measures. Measurement items were adapted from the technology acceptance model, customer perceived shopping value, flow theory, and mobile 
shopping intention literature. The items for measuring perceived ease of use (PEOU) and perceived usefulness (PU) constructs were adapted from Davis (1989), Venkatesh and Davis (2000), Pavlou (2003) and Chiu et al. (2009). Measures for mobile shopping attitude (MSA) construct were adapted from Ajzen and Fishbein (1980), Amaro and Duarte (2015). The items for measuring customer mobile shopping satisfaction construct items from Anderson and Srinivasan (2003), Ha and Perks (2005), and Chang and Chen (2008). Mobile shopping satisfaction construct items were included respondent's general feeling, happiness and overall satisfaction about the mobile shopping transactions. The items for measuring hedonic online shopping value (HMSV) and utilitarian mobile shopping value (UMSV) constructs were adapted from Babin et al. (1994), Teo et al. (2007) and O'Brien (2010). Measures for perceived enjoyment (PE) construct were adapted from Sweeney and Soutar (2001). The items for measuring flow (F) constructs were adapted from Payne, Jackson, Noh and Stine-Morrow (2011). Finally, measures for mobile shopping repurchase intention construct were adapted from Yoo and Donthu (2001), Pavlou (2003) and Chiu et al. (2009). In our survey instrument, each of the construct measures is designed to be reflective and all items are assessed by using a five-point Likert scale, ranging from 1 meaning (strongly disagree) to 5 (strongly agree).

The final section of the questionnaire contains questions about respondent's socio-demographic characteristics; such as age, gender, occupation, marital status, education level and income level. In this section, respondents were also asked for smartphone usage and mobile shopping behaviors; such as, used smartphone brand, mobile shopping experience level, average time spent on mobile shopping (every usage), frequent transactions via using smartphone, the most frequently bought items via mobile shopping, the number of items bought within six months, the frequency of mobile shopping within six months, mobile shopping satisfaction level.

\subsection{Data Analysis}

In the analysis process, we used Partial Least Squares Path Model (PLS-PM) technique. PLS-PM is a component-based structural equation modeling method to test theoretical relations between latent variables (Garson, 2016: 8). PLS-PM is characterized as a technique most suitable where the research purpose is a prediction or exploratory modeling. Therefore, Henseler et al., (2009) state that PLS path modeling is recommended in an early stage of theoretical development in order to test and validate exploratory models. The estimation procedure of PLS-PM is an ordinary least square regression method. PLS-PM uses observed data to estimate path coefficients in the research model with the objective of minimizing the explained variance of target endogenous construct. For this reason, PLS-PM is a variance-based approach to structural equation modeling (Hair, et al., 2016: 14). The estimation of PLS path model is conducted in four steps. Firstly, an iterative algorithm determining composite scores for each construct is performed. Then, corrections for attenuation for those modeled constructs are made. Thirdly, parameter estimation is made and finally, bootstrapping for inference testing is performed (Henseler et al. 2016). PLS-PM has some advantages over other SEM technique. For instance, PLS-PM analysis works more efficiently with a) complex theoretical models, b) small sample size, c) variable prediction goal, d)non-normal data distributions, and it uses e) both reflective and formative constructs (Willaby et al., 2015; Henseler et al., 2009). On the other hand, in the literature, the PLS-PM analysis method is generally criticized as four main headings. It is criticized as producing biased parameter estimates, offering no model over identification tests, not correcting for endogeneity in predictors, and not accommodating measurement error (e.g. Rönkkö et al., 2015; McIntosh et al., 2014; Rönkkö and Evermann, 2013). Overall, the mix of advantages and disadvantages of this technique we favored PLS-PM analysis to test exploratory research model. During the analyses process, SmartPLS 3 (Version 3.2.6) software (Ringle et al., 2015) was used to evaluate the measurement and structural model.

\section{Results}

\subsection{Demographic Characteristics of the Respondents}

A total of 400 respondents participated in this study. The demographic profile and mobile shopping behavior of respondents are summarized in Table 1 . Among the survey respondents, $59 \%$ were male; approximately $56 \%$ of the respondents were single. In terms of age level, with the most significant number of responses was the age level 18-25, with $40 \%$ of the total responses. According to the survey, the sample seems to be composed of highly educated individuals, with the $81 \%$ of the respondents indicated that they had completed an undergraduate degree. In terms of the average income, the most significant number of responses was the income level of 3.000-3.999 with $32 \%$ of the total responses. According to the survey, approximately $45 \%$ of the respondents gave their occupation as a government employee. Among the survey respondents, $23 \%$ of the respondents reported that they use Apple (iPhone) as a smartphone, $43 \%$ of the respondents reported that their mobile shopping experience level is good. In terms of the average time spent on mobile shopping (every usage), 
the group with the most significant number of responses was the less than 1 hour with the $41 \%$ of the total responses. According to the survey, product purchases were the frequent transactions on mobile shopping, with the $30 \%$ of the total responses. In terms of the most frequently bought items via mobile shopping, group with the most significant number of responses was the apparel, accessories, and footwear with $28 \%$ of the total responses. According to the survey, $33 \%$ of the respondents indicated that the number of items bought within six months was five and more. Among the survey respondents, the frequency of mobile shopping within six months, the group with the most significant number of responses was once or more every three months with the $42 \%$ of the total responses. Nearly $66 \%$ of the total respondents reported that their mobile shopping satisfaction level was good and above.

Table 1. Demographic characteristics and mobile shopping behavior of the sample $(n=400)$

\begin{tabular}{|c|c|c|c|c|c|}
\hline Gender & Frequency & Percent & Marital Status & Frequency & Percent \\
\hline Male & 237 & 59.2 & Single & 222 & 55.5 \\
\hline Female & 163 & 40.8 & Married & 178 & 44.5 \\
\hline Age & Frequency & Percent & Education level & Frequency & Percent \\
\hline $18-25$ & 160 & 40.0 & Elementary education & 1 & 0.3 \\
\hline $26-33$ & 71 & 17.8 & Secondary education & 9 & 2.3 \\
\hline $34-41$ & 94 & 23.5 & High school & 65 & 16.3 \\
\hline $42-49$ & 59 & 14.8 & Undergraduate & 270 & 67.5 \\
\hline $50-57$ & 12 & 3.0 & Postgraduate & 38 & 9.5 \\
\hline $58-65$ & 4 & 1.0 & Doctorate & 17 & 4.3 \\
\hline Occupation & Frequency & Percent & Monthly average income (TL) & Frequency & Percent \\
\hline Government supervisor & 16 & 4.0 & $0-1.300$ & 17 & 4.3 \\
\hline Private Sector- Supervisor & 41 & 10.3 & $1.301-1.999$ & 43 & 10.8 \\
\hline Government- Officer & 50 & 12.5 & $2.000-2.999$ & 93 & 23.3 \\
\hline Private Sector- Officer & 34 & 8.5 & $3.000-3.999$ & 130 & 32.5 \\
\hline Government- Employee & 8 & 2.0 & 4.000 and above & 117 & 29.3 \\
\hline Employee-Private Sector & 21 & 5.3 & Frequent transactions & Frequency & Percent \\
\hline Tradesman & 13 & 3.3 & Product Purchases & 120 & 30.0 \\
\hline Businessman & 15 & 3.8 & Service Purchases & 25 & 6.3 \\
\hline Retired & 6 & 1.5 & Banking Transactions & 45 & 11.3 \\
\hline Housewife & 8 & 2.0 & Booking & 19 & 4.8 \\
\hline Student & 176 & 44.0 & Buying tickets & 35 & 8.8 \\
\hline Academic Staff & 12 & 3 & Processing mobile payments & 26 & 6.5 \\
\hline Smartphone brand & Frequency & Percent & Coupons & 17 & 4.3 \\
\hline Apple (iPhone) & 94 & 23.5 & Shopping List & 24 & 6 \\
\hline Samsung & 66 & 16.5 & Product/Service Research & 89 & 22.3 \\
\hline Others & 240 & 60.0 & The most frequently bought items & Frequency & Percent \\
\hline M-shopping experience level & Frequency & Percent & Consumer electronics, mobiles and accessories & 79 & 19.8 \\
\hline Very bad & 3 & 0.8 & Apparel, accessories, and footwear & 113 & 28.3 \\
\hline Bad & 20 & 5.0 & Computer hardware and software & 58 & 14.5 \\
\hline Average & 102 & 25.5 & Food, beverages, and groceries & 27 & 6.8 \\
\hline Good & 173 & 43.3 & Books, movie tickets, and music & 59 & 14.8 \\
\hline Very Good & 102 & 25.5 & White goods, furniture & 14 & 3.5 \\
\hline Average time spent & Frequency & Percent & Others & 50 & 12.5 \\
\hline Less than 1 hour & 165 & 41.3 & The number of items bought within six months & Frequency & Percent \\
\hline $1-2$ hours & 143 & 35.8 & 1 & 38 & 9.5 \\
\hline 3-4 hours & 70 & 17.5 & 2 & 58 & 14.5 \\
\hline $5-6$ hours & 22 & 5.5 & 3 & 63 & 15.8 \\
\hline M-shopping satisfaction level & Frequency & Percent & 4 & 108 & 27 \\
\hline $\mathrm{Bad}$ & 26 & 6.5 & 5 and above & 133 & 33.3 \\
\hline Average & 112 & 28.0 & The frequency of M-shopping within six months & Frequency & Percent \\
\hline Good & 152 & 38.0 & Seldom (Once or twice) & 73 & 18.3 \\
\hline \multirow[t]{3}{*}{ Very Good } & 110 & 27.5 & Once or more every three months & 168 & 42.0 \\
\hline & & & Once or more per month & 124 & 31.0 \\
\hline & & & Once or more per week & 35 & 8.8 \\
\hline
\end{tabular}




\subsection{Measurement Model Assessment}

PLS-PM consists of two sets of linear equations, one is the outer model, and the other is the inner model (Vinzi et al., 2010). The outer model indicates the relationships between a latent variable and it is observed or manifests variables, whereas the inner model specifies the relationships between unobserved or latent variables (Henseller et al., 2009). Thus, the first step in the PLS-PM analysis is the assessment of the measurement model. Reliable and valid measurement model estimations allow us an evaluation of structural path model estimates. In order to evaluate the psychometric properties of the reflective measurement model, this study followed the procedure offered by Hair et al. (2016) in the PLS-PM analysis process. Reliability, convergent and discriminant validity and average variance extracted (AVE) indices were evaluated for the measurement models.

During the measurement model assessment, firstly, reliability was evaluated by the criterion, Cronbach's $\alpha$ larger than 0.70 . Convergent validity was evaluated by three criteria: 1$)$ item loadings $(\lambda)$ larger than 0.708 and statistical significance, 2) composite construct reliability larger than 0.80 and 3) average variance extracted (AVE) larger than 0.50 (Fornell and Lacker, 1981; Chin, 1998; Hair et al., 2016). Secondly, discriminant validity was evaluated by the criterion, the square root of AVE for each latent construct larger than its correlations with all other latent constructs (Fornell \& Lacker, 1981).

Table 2. Constructs' convergent validity and reliability

\begin{tabular}{lccccc}
\hline Constructs & Items & $\begin{array}{c}\text { Item } \\
\text { loadings* }(\lambda)\end{array}$ & $\begin{array}{c}\text { Cronbach's } \\
\boldsymbol{\alpha}\end{array}$ & $\begin{array}{c}\text { Composite } \\
\text { reliability }\end{array}$ & AVE \\
\hline Perceived ease of use (PEOU) & 5 & $0.782-0.877$ & 0.902 & 0.928 & 0.720 \\
Perceived usefulness (PU) & 5 & $0.801-0.900$ & 0.908 & 0.932 & 0.733 \\
Perceived enjoyment (PE) & 5 & $0.878-0.922$ & 0.943 & 0.946 & 0.814 \\
Flow experience(FE) & 25 & $0.709-0.917$ & 0.948 & 0.949 & 0.568 \\
Mobile shopping attitude (MSA) & 5 & $0.864-0.902$ & 0.929 & 0.947 & 0.780 \\
Perceived utilitarian value (PUV) & 5 & $0.807-0.874$ & 0.905 & 0.922 & 0.703 \\
Perceived hedonic value (PHV) & 10 & $0.733-0.842$ & 0.932 & 0.943 & 0.624 \\
Mobile shopping satisfaction(MSS) & 4 & $0.783-0.939$ & 0.913 & 0.939 & 0.795 \\
Mobile repurchase intentions (MRI) & 7 & $0.880-0.925$ & 0.923 & 0.937 & 0.817 \\
\hline
\end{tabular}

Note. *Reflective measurement model factor loadings are statistically significant at $(\mathrm{p}<0.001)$.

As indicated in Table 2, standardized item loadings are statistically significant $(\mathrm{p}<0.001)$ on their respective construct and range from 0.709 to 0.939 . Cronbach's $\alpha$ coefficient range from 0.902 to 0.948 and all are above the recommended level of 0.70 . Analysis result indicates that all reflective constructs have a satisfactory level of internal consistency reliability. Composite construct reliabilities range from 0.922 to 0.949 and all above the recommended level of 0.80 . Analysis result indicates that all the reflective constructs have a high level of internal consistency. Average variance extracted (AVE) values range from 0.568 to 0.817 and all above the minimum recommended level of 0.50 . This indicates the convergent validity for all constructs.

In Table 3, diagonal elements (values in parentheses) are the square root of the AVE; the off-diagonal values are the correlations between the latent constructs. Analysis result reveals that the square root of the AVE for each construct is larger than its correlations with all other constructs. The analysis result supports reflective measurement constructs' discriminant validity. Thus, analysis results show an acceptable level of reliability, convergent and discriminant validity. Therefore, analysis results imply that our data and measurement model are suitable for structural model assessment and hypothesis testing process. 
Table 3. Constructs' discriminant validity

\begin{tabular}{|c|c|c|c|c|c|c|c|c|c|c|c|}
\hline Constructs & Mean & SD & PEOU & $\mathbf{P U}$ & $\mathbf{P E}$ & $\mathbf{F E}$ & MSA & PUV & PHV & MSS & MRI \\
\hline Perceived ease of use & 4.012 & .793 & $(.849)$ & & & & & & & & \\
\hline Perceived usefulness & 3.989 & .751 & .529 & $(.856)$ & & & & & & & \\
\hline Perceived enjoyment & 3.828 & .777 & .496 & .582 & $(.902)$ & & & & & & \\
\hline Flow experience & 3.872 & .725 & .595 & .412 & .577 & $(.754)$ & & & & & \\
\hline Mobile shopping attitude & 3.920 & .725 & .539 & .645 & .410 & .603 & $(.883)$ & & & & \\
\hline Perceived utilitarian value & 4.112 & .715 & .532 & .634 & .386 & .435 & .580 & $(.838)$ & & & \\
\hline Perceived hedonic value & 3.689 & .788 & .453 & .578 & .511 & .583 & .606 & .539 & $(.790)$ & & \\
\hline Mobile shopping satisfaction & 3.787 & .782 & .497 & .544 & .690 & .561 & .623 & .421 & .687 & $(.892)$ & \\
\hline Mobile repurchase intentions & 3.732 & .926 & .377 & .355 & .515 & .478 & .525 & .381 & .586 & .692 & $(.904)$ \\
\hline
\end{tabular}

Note. Square roots of AVEs are presented on the diagonal. Construct correlations are shown below the diagonal. Perceived ease of use (PEOU), Perceived usefulness (PU), Perceived enjoyment (PE), Flow experience (FE), Mobile shopping attitude (MSA), Perceived utilitarian value (PUV), Perceived hedonic value (PHV), Mobile shopping satisfaction (MSS), Mobile repurchase intentions (MRI).

\subsection{Structural Model Assessment}

As mentioned above, having the measurement model has been confirmed as reliable and valid, then, the next step is to evaluate the structural model results, which involves examining the model's predictive capabilities and the relationships between the constructs. According to Hair et al. (2014, p. 169), the key criteria for evaluating the structural model in PLS-PM are the significance of path coefficient, the level of latent variables $\mathrm{R}^{2}$ values, the predictive relevance $\left(\mathrm{Q}^{2}\right)$ values.

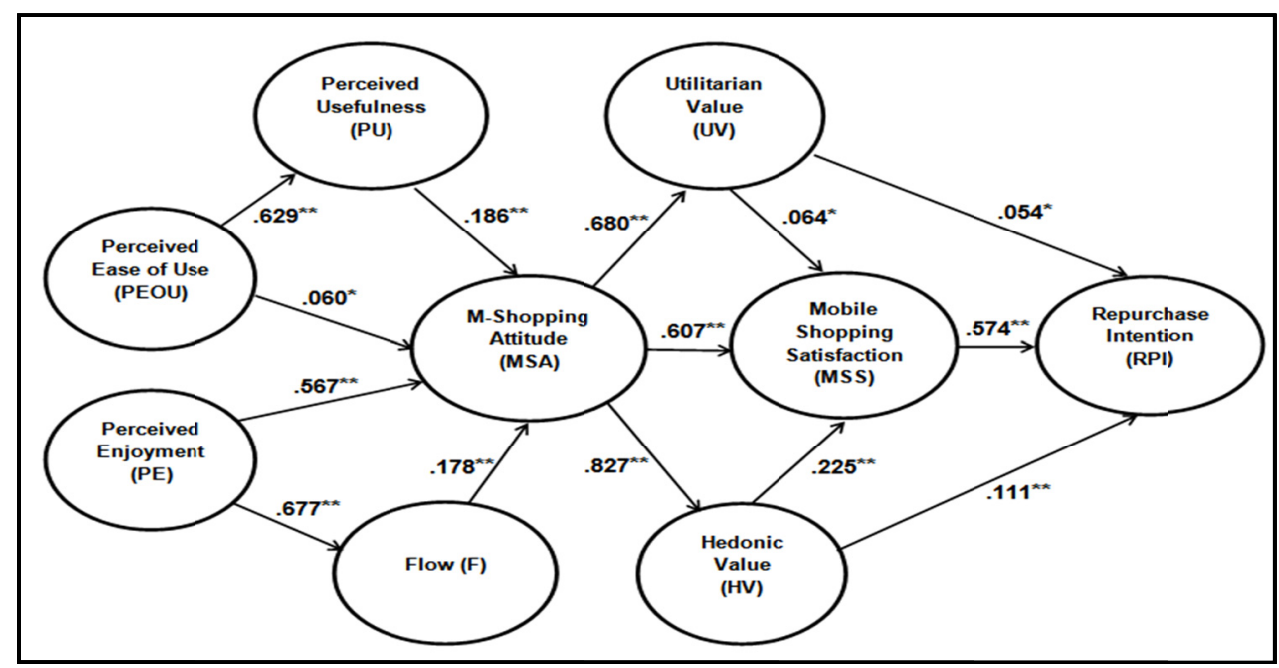

Figure 2. Results of path analysis $(*: \mathrm{p}<0.05 ; * *: \mathrm{p}<0.01$.)

The evaluations of the structural research model base on the bootstrapping and blindfolding procedure (Hair et al., 2014). After managing the PLS-PM algorithm, the path coefficient estimates (see Figure 2) were obtained for the structural model relationships, which represent the hypothesized relationships between the latent constructs. The statistical significance levels of path coefficients were estimated by means of bootstrapping routine (5.000 subsample and 400 bootstrap cases). In order to assess the models' predictive relevance, Stone-Geisser's $\mathrm{Q}^{2}$ values were also obtained via the blindfolding procedure. Table 4 shows the results of the structural relationship path coefficients, standard deviations for path coefficients, t-statistic values, p-values, and hypothesis test results. 
Table 4. PLS-PM hypothesis test results

\begin{tabular}{|c|c|c|c|c|c|c|}
\hline Hypothesized Relationships & $\begin{array}{c}\text { Path } \\
\text { Coefficient }\end{array}$ & $\begin{array}{c}\text { Standard } \\
\text { Error }\end{array}$ & $\begin{array}{c}\text { T- } \\
\text { Statistic }^{*}\end{array}$ & P-Value & Hypothesis & Decision \\
\hline Peou ---> Pu & 0.629 & 0.040 & $15.564^{* *}$ & 0.000 & $\mathrm{H}_{1}$ & Supported \\
\hline Peou ---> M-shopattitude & 0.060 & 0.028 & $2.142^{*}$ & 0.032 & $\mathrm{H}_{2}$ & Supported \\
\hline $\mathrm{Pu}$---> M-shopattitude & 0.186 & 0.039 & $4.769^{* *}$ & 0.000 & $\mathrm{H}_{3}$ & Supported \\
\hline Penjoy ---> Flow experience & 0.677 & 0.035 & $19.384^{* *}$ & 0.000 & $\mathrm{H}_{4}$ & Supported \\
\hline Penjoy ---> M-shopattitude & 0.567 & 0.041 & $13.785^{* *}$ & 0.000 & $\mathrm{H}_{5}$ & Supported \\
\hline Flow experience ---> M-shopattitude & 0.178 & 0.043 & $4.108^{* *}$ & 0.000 & $\mathrm{H}_{6}$ & Supported \\
\hline M-shopattitude->M-shopsatisfaction & 0.607 & 0.055 & $11.018^{* *}$ & 0.000 & $\mathrm{H}_{7}$ & Supported \\
\hline M-shopattitude---> Utilitarian value & 0.680 & 0.039 & $17.387^{* *}$ & 0.000 & $\mathrm{H}_{8}$ & Supported \\
\hline M-shopattitude ---> Hedonic value & 0.827 & 0.019 & 44.048 & 0.000 & $\mathrm{H}_{9}$ & Supported \\
\hline Utilitarian value ---> M-shopsatisfaction & 0.064 & 0.031 & $2.061^{*}$ & 0.039 & $\mathrm{H}_{10}$ & Supported \\
\hline Utilitarian value--> M-repurchaseintentions & 0.054 & 0.024 & $2.251^{*}$ & 0.024 & $\mathrm{H}_{11}$ & Supported \\
\hline Hedonic value ---> M-shopsatisfaction & 0.225 & 0.054 & $4.175^{* *}$ & 0.000 & $\mathrm{H}_{12}$ & Supported \\
\hline Hedonic value ---> M-repurchaseintens & 0.111 & 0.038 & $2.921^{* *}$ & 0.003 & $\mathrm{H}_{13}$ & Supported \\
\hline M-shopsatisfaction---> M-repurchaseintentions & 0.574 & 0.060 & $9.492^{* *}$ & 0.000 & $\mathrm{H}_{14}$ & Supported \\
\hline
\end{tabular}

Note. t-values for two-tailed test; $* 1.96$ (sig.level $5 \%), * * 2.58$ (sig.level $1 \%)$.

PLS-PM analysis result reveals that the perceived ease of use construct has a positive and statistically significant effect on the perceived usefulness construct $(\beta=0.629, \mathrm{P}<0.01)$. This result empirically supports Hypothesis 1 . In addition, the perceived ease of use construct has a positive and statistically significant effect on mobile shopping attitude construct $(\beta=0.06, \mathrm{P}<0.05)$. This result empirically supports Hypothesis 2 . Moreover, perceived usefulness construct has a positive and statistically significant effect on mobile shopping attitude construct $(\beta=0.186, \mathrm{P}<0.01)$. This result empirically supports Hypothesis 3. According to PLS-PM results, perceived enjoyment construct has a positive and statistically significant effect on mobile shopping flow experience construct $(\beta=0.677, \mathrm{P}<0.01)$. This result empirically supports Hypothesis 4 . Moreover, perceived enjoyment construct has a positive and statistically significant effect on mobile shopping attitude construct $(\beta=0.567$, $\mathrm{P}<0.01$ ). This result empirically supports Hypothesis 5. Furthermore, the mobile shopping flow experience construct has a positive and statistically significant effect on mobile shopping attitude construct $(\beta=0.178$, $\mathrm{P}<0.01$ ). This result empirically supports Hypothesis 6 . The current study found that perceived ease of use, perceived usefulness beliefs about mobile shopping, perceived enjoyment, and mobile shopping flow experience are significant determinants of consumers' mobile shopping attitude. Analysis result reveals that the effect of perceived enjoyment dimension is relatively the highest effect on consumers' mobile shopping attitude. The results indicate that perceived enjoyment and mobile shopping flow experience are an important determinant of consumers' mobile shopping attitude.

According to the PLS-PM analysis result, mobile shopping attitude dimension has a positive and statistically significant effect on mobile shopping satisfaction construct $(\beta=0.607, \mathrm{P}<0.01)$. This result empirically supports Hypothesis 7. In addition, mobile shopping attitude dimension has a positive and statistically significant effect on perceived utilitarian value construct $(\beta=0.680, \mathrm{P}<0.01)$. This result empirically supports Hypothesis 8 . Also, mobile shopping attitude dimension has a positive and statistically significant effect on perceived hedonic value construct $(\beta=0.827, \mathrm{P}<0.01)$. This result empirically supports Hypothesis 9 . The current study found that positive mobile shopping attitude impacts on mobile shopping satisfaction, perceived utilitarian value, and perceived hedonic value dimensions. Analysis result reveals that the effect of mobile shopping attitude dimension is relatively the highest effect on consumers' perceived hedonic value dimension.

PLS-PM analysis results indicate that perceived utilitarian value construct has a positive and statistically significant effect on mobile shopping satisfaction construct $(\beta=0.064, \mathrm{P}<0.05)$. This result empirically supports Hypothesis 10. In addition, perceived utilitarian value construct has a positive and statistically significant effect 
on mobile repurchase intentions dimension $(\beta=0.054, \mathrm{P}<0.05)$. This result empirically supports Hypothesis 11 . Also, analysis result shows that perceived hedonic value construct has a positive and statistically significant effect on mobile shopping satisfaction construct $(\beta=0.225, \mathrm{P}<0.01)$. This result empirically supports Hypothesis 12. Moreover, perceived hedonic value construct has a positive and statistically significant effect on mobile repurchase intentions dimension $(\beta=0.111, \mathrm{P}<0.01)$. This result empirically supports Hypothesis 13 . Therefore, the current study found that perceived hedonic value dimension has a higher-level relative effect on both mobile satisfaction and mobile repurchase intentions when compared to perceived utilitarian value dimension. Finally, mobile shopping satisfaction construct has a positive and statistically significant effect on mobile repurchase intentions construct $(\beta=0.574, \mathrm{P}<0.01)$. This result empirically supports Hypothesis 14 . This study found that mobile shopping satisfaction dimension has a higher-level relative effect on mobile repurchase intentions construct when compared to both hedonic and utilitarian value dimensions.

Finally, to examine the predictive accuracy and predictive relevance of the research model: $\mathrm{R}^{2}$ (coefficient of determination) and Stone-Geisser's $\mathrm{Q}^{2}$ values were also obtained by using the PLS algorithm procedure (see Table 5). As the endogenous latent construct, the $\mathrm{R}^{2}$ value for mobile repurchase intentions was calculated as 0.488 with a Stone-Geisser's $\mathrm{Q}^{2}$ value of 0.368 , indicating a large effect size. Therefore, PLS-PM analysis results reveal that the research model fits the data well.

Table 5. PLS results for endogenous latent construct predictive accuracy and relevance

\begin{tabular}{lccc}
\hline Endogenous Latent Constructs & $\mathbf{R}^{2}$ & $\mathbf{Q}^{2}$ & Effect Size* $^{\mathbf{2}}$ \\
\hline Perceived usefulness & 0.396 & 0.360 & Large \\
Flow experience & 0.458 & 0.238 & Medium \\
Mobile shopping attitude & 0.793 & 0.576 & Large \\
Perceived utilitarian value & 0.462 & 0.299 & Medium \\
Perceived hedonic value & 0.684 & 0.387 & Large \\
Mobile shopping satisfaction & 0.721 & 0.537 & Large \\
Mobile repurchase intentions & 0.488 & 0.368 & Large \\
\hline
\end{tabular}

Note. * Assessing predictive relevance $\left(\mathrm{Q}^{2}\right)$ value of the effect size: $0.02=$ Small, $0.15=$ Medium, $0.35=$ Large.

\section{Conclusions and Implications}

As an emerging concept, mobile shopping has become an indispensable reality for shoppers in today's living conditions. With the fast advancement of mobile internet, mobile shopping transactions actualize elastically. Mobile applications are endeavoring to impress mobile user's shopping attitude and behavior via shaping mobile shopping experience, to enable a shopping environment without inhibitive factors such as time and location. This situation provides mobile shoppers to make purchases with no restrictions. As long as mobile shopping has been included almost each mobile shopper's life cycle, mobile shopping notion has changed into an opportunity for users to take actions such as search, browse, compare and purchase goods or services in mobile platforms without any limitations of suppliers or retailers. Thus, the current study's purpose was to determine antecedents of the mobile re-purchase intentions. The present study expands the technology acceptance model, (TAM) and consumer value theory, by involving consumer perceived utilitarian and hedonic value, perceived enjoyment, flow experience dimension and mobile shopping satisfaction on the purpose of identifying the effects of users' perceived mobile shopping beliefs, mobile shopping attitudes, perceived utilitarian and hedonic value, and satisfaction components on users' mobile shopping intention.

The study results ensure significant support for the proposed research model of mobile shopping intentions. The present study determined that perceived ease of use, perceived usefulness about mobile shopping, perceived enjoyment, and mobile shopping flow experience are predictive factors of users' mobile shopping attitude. Moreover, the current study found that the effect of perceived enjoyment is comparatively the highest effect on users' mobile shopping attitude. The results show that perceived enjoyment and mobile shopping flow experience are the significant factors of users' mobile shopping attitude. The results are in line with the findings of TAM-based former studies on new technology adoptions and users' mobile shopping intentions (e.g. Davis et al.1989; Bloch et al.,1986; Adams et al., 1992; Teo et al., 1999; Novak et al., 2000; Childers et al., 2001, Pavlou, 2003; Skadberg and Kimmel, 2004; Lin, 2007; Lu and Su, 2009; Ko et al., 2009; Hoffman \& Novak, 
2009; Guo \& Poole, 2009; Zhou, 2013). Thus, the present study asserts that if mobile users consider that mobile shopping will benefit to improve their sense of fun, users may have good attitude related to mobile shopping.

Furthermore, the present study revealed that positive mobile shopping attitude has an influence on mobile shopping satisfaction, perceived utilitarian value and perceived hedonic value dimensions. The study result shows that mobile shopping attitude dimension is comparatively the highest effect on users' perceived hedonic value dimension. The current study results are consistent with the findings of previous studies related to users' repurchase intentions within the online shopping context (e.g. Childers et al., 2001; Kim \& Kang, 2001; Overby \& Lee, 2006; Teo et al., 2007; Green Atkins \& Kim, 2012). Thus, this study indicates that to enhance users' perception of utilitarian value, mobile retailers must enable to users a large variety of goods and services with minimum prices, and providing similar quality goods or services at the lower price level, rapid-access to extensive of goods and services information and more practical and easy shopping platform. Besides this, mobile shoppers have hedonic demands such as more fun and pleasure to improve their mood in comparison with utilitarian expectations. As a consequence, the present study proposes that on the purpose of enhancing mobile shopper perceptions of hedonic perspective, mobile retailers must enable entertaining shopping opportunity.

In addition, the analysis results reveal that perceived hedonic value dimension has a higher-level relative effect on both mobile satisfaction and mobile repurchase intentions when compared to perceived utilitarian value dimension. This result is in line with the findings of previous studies on repurchase intention within online shopping context. (e.g. Wolfinbarger \& Gilly, 2001; Anderson \& Srinivasan, 2003; Ha \& Perks, 2005; Seock \& Bailey, 2008; Chang \& Chen, 2008). Thus, the current study proposes that mobile retailers must try to find better solutions for high-level entertaining activities in an attempt to enhance shoppers' mobile satisfaction level.

Finally, the current study result shows that mobile shopping satisfaction dimension has a higher-level relative effect on mobile repurchase intentions construct in comparison with both hedonic and utilitarian value dimensions. These results are consistent with the findings of former studies on repurchase intention within online shopping context (Anderson \& Srinivasan, 2003; Shankar et al., 2002; Devaraj et al., 2003; Reynalds \& Arnold, 2006). Therefore, the present study proposes that to constitute mobile shopping intentions and to provide the sustainability of mobile shopping via using mobile devices, mobile platforms and retailers must satisfy the shoppers' demands and accelerate their utilitarian and hedonic values.

In conclusion, the current study expands the technology acceptance model (TAM) and consumer value theory. The analysis results enable significant support for the proposed research model of mobile shopping intentions. As a consequence, the results propose that mobile shoppers' beliefs and attitudes concerned with mobile shopping, perceived hedonic and utilitarian value and mobile shopping satisfaction clarify shopper's mobile shopping intentions.

\section{Limitations and Future Research}

From a theoretical perspective, this research provides various beneficial comprehensions about mobile shopping intentions. Nevertheless, the study results should be examined with following diverse limitations. The first limitation is that non-probability convenience sampling method was used in this study. The mentioned sampling method limited the implementation of the study findings to the entire population. Thus, future study should use the probability-sampling method and examine the research model again. Their findings will henceforth generalize to the entire population. The second limitation is that the data were gathered from only Adana City residents in Turkey which may cause sampling bias, hence future study expand this research and the model to other human groups. Finally, the antecedents of mobile shopping intentions defined a significant amount of its variance in our research model, but the other external factors that have not been involved in the model may assist to explain mobile shopping intentions. For instance, compatibility and anxiety ( $\mathrm{Lu}$ and $\mathrm{Su}, 2009)$, trust, privacy (Lai et al. 2012), risk and uncertainty (Siau et al., 2003) dimensions might better provide the comprehension of mobile shopping intentions from the viewpoint of flow dimension and other external variables. In accordance with these assessments, the results of the current study will be an inspiration to future studies and enable beneficial information for them.

\section{References}

Agarwal, R., \& Karahanna, E. (2000). Time flies when you're having fun: Cognitive absorption and beliefs about information technology usage. MIS Quarterly, 665-694. http://dx.doi.org/10.2307/3250951

Agrebi, S., \& Jallais, J. (2015). Explain the intention to use smartphones for mobile shopping. Journal of Retailing and Consumer Services, 22, 16-23. http://dx.doi.org/10.1016/j.jretconser.2014.09.003

Ajzen, I., \& Madden, T. J. (1986). Prediction of goal-directed behavior: Attitudes, intentions, and perceived 
behavioral control. Journal of Experimental Social Psychology, 22(5), 453-474. http://dx.doi.org/10.1016/0022-1031(86)90045-4

Aldás-Manzano, J., Ruiz-Mafe, C., \& Sanz-Blas, S. (2009). Exploring individual personality factors as drivers of M-shopping acceptance. Industrial Management \& Data Systems, 109(6), 739-757. http://dx.doi.org/10.1108/02635570910968018

Anderson, R. E., \& Srinivasan, S. S. (2003). E-satisfaction and e-loyalty: A contingency framework. Psychology \& Marketing, 20(2), 123-138. http://dx.doi.org/ 10.1002/mar.10063

Anil, S., Ting, L. T., Moe, L. H., \& Jonathan, G. P. G. (2003). Overcoming barriers to the successful adoption of mobile commerce in Singapore. International Journal of Mobile Communications, 1(1-2), 194-231. http://dx.doi.org/10.1504/IJMC.2003.002466

Animesh, A., Pinsonneault, A., Yang, S. B., \& Oh, W. (2011). An odyssey into virtual worlds: Exploring the impacts of technological and spatial environments on intention to purchase virtual products. MIS Quarterly-Management Information Systems, 35(3), 789-810.

Arning, K., \& Ziefle, M. (2007). Understanding age differences in PDA acceptance and performance. Computers in Human Behavior, 23(6), 2904-2927. http://dx.doi.org/10.1016/j.chb.2006.06.005

Babin, B. J., Darden, W. R., \& Griffin, M. (1994). Work and/or fun: measuring hedonic and utilitarian shopping value. Journal of Consumer Research, 644-656._http://dx.doi.org/10.1086/209376

Balasubramanian, S., Peterson, R. A., \& Jarvenpaa, S. L. (2002). Exploring the implications of m-commerce for markets and marketing. Journal of the Academy of Marketing Science, 30(4), 348-361. http://dx.doi.org/10.1177/009207002236910

Batra, R., \& Ahtola, O. T. (1991). Measuring the hedonic and utilitarian sources of consumer attitudes. Marketing Letters, 2(2), 159-170. http://dx.doi.org/10.1007/BF00436035

Bhattacherjee, A. (2001). Understanding information systems continuance: an expectation-confirmation model. MIS quarterly, 351-370. http://dx.doi.org/10.2307/3250921

Bhatti, T. (2007). Exploring factors influencing the adoption of mobile commerce. Journal of Internet Banking and Commerce, 12(3), 1-13.

Bigne-Alcaniz, E., Ruiz-Mafe, C., Aldas-Manzano, J., \& Sanz-Blas, S. (2008). Influence of online shopping information dependency and innovativeness on internet shopping adoption. Online Information Review, 32(5), 648-667. http://dx.doi.org/10.1108/14684520810914025

Bloch, P. H., Sherrell, D. L., \& Ridgway, N. M. (1986). Consumer search: An extended framework. Journal of Consumer Research, 119-126. http://dx.doi.org/10.1086/209052

Bruner, G. C., \& Kumar, A. (2005). Explaining consumer acceptance of handheld Internet devices. Journal of Business Research, 58(5), 553-558._http://dx.doi.org/10.1016/j.jbusres.2003.08.002

Budzanowska-Drzewiecka, M. (2015). Individual determinants of propensity to make purchases as part of e-commerce and m-commerce in Polish young consumers. Jagiellonian Journal of Management, (Numer 1), 7-21._http://dx.doi.org/10.4467/2450114XJJM.15.001.3808

Chang, H. H. (2006). Technical and management perceptions of enterprise information system importance, implementation and benefits. Information Systems Journal, 16(3), 263-292. http://dx.doi.org/10.1111/j.1365-2575.2006.00217.x

Chin, W. W. (1998). The partial least squares approach to structural equation modeling. Modern methods for business research, 295(2), 295-336.

Chiu, H. C., Hsieh, Y. C., \& Kao, C. Y. (2005). Website quality and customer's behavioral intention: An exploratory study of the role of information asymmetry. Total Quality Management and Business Excellence, 16(2), 185-197._http://dx.doi.org/10.1080/14783360500054277

Cox, J. (2004). Ubiquitous consumption and the marketing mix. Journal of Internet Commerce, 3(2), 21-32. http://dx.doi.org/10.1300/J179v03n02_02

Csíkszentmihályi, M. \& Csíkszentmihályi, I.S. (1988) Introduction to Part IV. In: Optimal Experience: Psychological Studies of Flow in Consciousness, Csíkszentmihályi, M. \& Csíkszentmihályi, I.S. (eds), pp. 251-265. Cambridge University Press, Cambridge, UK.

Csíkszentmihályi, M. (1975) Beyond Boredom and Anxiety: Experiencing Flow in Work and Play. Jossey- Bass, 
San Francisco, CA, USA.

Csíkszentmihályi, M. (1990) Flow: The Psychology of Optimal Experience, Harper \& Row, New York.

Csíkszentmihályi, M. (1997). Finding flow: The psychology of engagement with everyday life. Basic Books.

Csíkszentmihályi, M., \& LeFevre, J. (1989). Optimal experience in work and leisure. Journal of Personality and Social Psychology, 56(5), 815-822._http://dx.doi.org/10.1037/0022-3514.56.5.815

Davis, F. D. (1989). Perceived Usefulness, Perceived Ease of Use, and User Acceptance of Information Technology. MIS Quarterly 13, 319-340._http://dx.doi.org/10.2307/249008

Davis, F. D., Bagozzi, R. P., \& Warshaw, P. R. (1989). User acceptance of computer technology: A comparison of two theoretical models. Management science, 35(8), 982-1003._http://dx.doi.org/10.1287/mnsc.35.8.982

Davis, F. D., Bagozzi, R. P., \& Warshaw, P. R. (1992). Extrinsic and intrinsic motivation to use computers in the workplace1. Journal of Applied Social Psychology, 22(14), 1111-1132. http://dx.doi.org/10.1111/j.1559-1816.1992.tb00945.x

Devaraj, S., \& Kohli, R. (2003). Performance impacts of information technology: Is actual usage the missing link? Management science, 49(3), 273-289._http://dx.doi.org/10.1287/mnsc.49.3.273.12736

Devaraj, S., Fan, M., \& Kohli, R. (2002). Antecedents of B2C channel satisfaction and preference: validating e-commerce metrics. Information systems research, 13(3), 316-333.

Djamasbi, S., Strong, D. M., \& Dishaw, M. (2010). Affect and acceptance: Examining the effects of positive mood on the technology acceptance model. Decision Support Systems, 48(2), 383-394. http://dx.doi.org/10.1016/j.dss.2009.10.002

Dodds, W. B., Monroe, K. B., \& Grewal, D. (1991). Effects of price, brand, and store information on buyers' product evaluations. Journal of Marketing Research, 307-319._http://dx.doi.org/10.2307/3172866

e-Marketer. (2013). More Shoppers Reach for Mobile to Browse. Retrieved from http://www.emarketer.com/Article/More-Shoppers-Reach-Mobile-Browse-Buy/1009615

Esposito Vinzi V., Trinchera L., Amato S. (2010). PLS path modeling: From foundations to recent developments and open issues for model assessment and improvement. In Esposito Vinzi V., Chin W. W., Henseler J., Wang H. Eds. 2010. Handbook of partial least squares: Concepts, methods and applications (Springer handbooks of computational statistics series, vol. 2, pp. 47-82). Heidelberg, Germany. http://dx.doi.org/10.1007/978-3-540-32827-8_3

Fenech, T. (2002). Exploratory study into wireless application protocol shopping. International Journal of Retail \& Distribution Management, 30(10), 482-497. http://dx.doi.org/10.1108/09590550210445353

Fishbein, M., \& Ajzen, I. (1975). Belief, attitude, intention and behavior: an introduction to theory and research. Massachusetts, Addison-Wiley Publishing Company.

Fornell C., Larcker D. F. (1981). Evaluating structural equation models with unobservable variables and measurement error. Journal of Marketing Research, 18(1), 39-50. http://dx.doi.org/10.2307/3151312

Garson, G. David. (2016). Partial Least Squares Regression and Structural Equation Models. 2016 Edition (Statistical Associates Blue Book Series 10), Statistical Associates Publishing, USA.

Gefen, D. (2003). TAM or just plain habit: A look at experienced online shoppers. Journal of Organizational and End User Computing (JOEUC), 15(3), 1-13. http://dx.doi.org/10.4018/joeuc.2003070101

Gefen, D., \& Straub, D. W. (1997). Gender differences in the perception and use of e-mail: An extension to the technology acceptance model. MIS quarterly, 389-400. http://dx.doi.org/10.2307/249720

Gefen, D., \& Straub, D. W. (2000). The relative importance of perceived ease of use in IS adoption: A study of e-commerce adoption. Journal of the Association for Information Systems, 1(1), 1-28.

Gillenson, M. L., \& Sherrell, D. L. (2002). Enticing online consumers: an extended technology acceptance $\begin{array}{llllll}\text { perspective. Information } \quad \& \quad \text { management, } & 39 & (8), & \text { 705-719. }\end{array}$ http://dx.doi.org/10.1016/S0378-7206(01)00127-6

Green Atkins, K., \& Kim, Y. K. (2012). Smart shopping: conceptualization and measurement. International Journal of Retail \& Distribution Management, 40(5), 360-375. http://dx.doi.org/10.1108/09590551211222349

Groß, M. (2015). Exploring the acceptance of technology for mobile shopping: an empirical investigation among 
Smartphone users. The International Review of Retail, Distribution and Consumer Research, 25(3), 215-235._http://dx.doi.org/10.1080/09593969.2014.988280

Guo, Y. M., \& Poole, M. S. (2009). Antecedents of flow in online shopping: a test of alternative models. Information Systems Journal, 19(4), 369-390. http://dx.doi.org/10.1111/j.1365-2575.2007.00292.x

Ha, I., Yoon, Y., \& Choi, M. (2007). Determinants of adoption of mobile games under mobile broadband wireless access environment. Information \& $\quad$ Management, $44(3), \quad 286$. http://dx.doi.org/10.1016/j.im.2007.01.001

Hair Jr, J. F., Hult, G. T. M., Ringle, C., and Sarstedt, M. (2016). A primer on partial least squares structural equation modeling (PLS-SEM). Second Edition, Sage Publications.

Hair, J. F., Hult, G. T. M., Ringle, C., and Sarstedt, M. (2014). A primer on partial least squares structural equation modeling (PLS-SEM). Sage Publications.

Harris, L. C., \& Goode, M. M. (2004). The four levels of loyalty and the pivotal role of trust: a study of online service dynamics. Journal of retailing, 80(2), 139-158._http://dx.doi.org/10.1016/j.jretai.2004.04.002

Heinemann, G., and C. Schwarzl. 2010. New Online Retailing: Innovation and Transformation. 1sted. Wiesbaden: Gabler.

Hellier, P. K., Geursen, G. M., Carr, R. A., \& Rickard, J. A. (2003). Customer repurchase intention: A general structural equation model. European journal of marketing, 37(11/12), 1762-1800. http://dx.doi.org/10.1108/03090560310495456

Henseler, J., Hubona, G., and Ray, P. A. (2016). Using PLS path modeling in new technology research: updated guidelines. Industrial management and data systems, 116(1), 2-20. http://dx.doi.org/10.1108/IMDS-09-2015-0382

Henseler, J., Ringle, C. M., and Sinkovics, R. R. (2009). The use of partial least squares path modeling in international marketing. Advances in International Marketing, (20), 277-320. https://doi.org/10.1108/S1474-7979(2009)0000020014

Ho, L. A., \& Kuo, T. H. (2010). How can one amplify the effect of e-learning? An examination of high-tech employees' computer attitude and flow experience. Computers in Human Behavior, 26(1), 23-31. http://dx.doi.org/10.1016/j.chb.2009.07.007

Hoffman, D. L., \& Novak, T. P. (1996). Marketing in hypermedia computer-mediated environments: Conceptual foundations. The Journal of Marketing, 50-68. http://dx.doi.org/10.2307/1251841

Hoffman, D. L., \& Novak, T. P. (2009). Flow online: lessons learned and future prospects. Journal of Interactive Marketing, 23(1), 23-34._http://dx.doi.org/10.1016/j.intmar.2008.10.003

Holbrook, M. B., \& Hirschman, E. C. (1982). The experiential aspects of consumption: Consumer fantasies, feelings, and fun. Journal of consumer research, 132-140_.http://dx.doi.org/10.1086/208906

Holmes, A., Byrne, A., \& Rowley, J. (2013). Mobile shopping behavior: insights into attitudes, shopping process involvement and location. International Journal of Retail \& Distribution Management, 42(1), 25-39. http://dx.doi.org/10.1108/IJRDM-10-2012-0096

Howard, J. A., \& Sheth, J. N. (1969). The theory of buyer behavior. New York: Wiley.

Hsu, C. L., \& Lu, H. P. (2004). Why do people play on-line games? An extended TAM with social influences and flow experience. Information \& $\quad$ Management, $41(7), \quad$ 853-868. http://dx.doi.org/10.1016/j.im.2003.08.014

Hume, M. (2008). Understanding core and peripheral service quality in customer repurchase of the performing arts. Managing Service Quality: An International Journal, 18(4), 349-369. http://dx.doi.org/10.1108/09604520810885608

Hung, M. C., Yang, S. T., \& Hsieh, T. C. (2012). An examination of the determinants of mobile shopping continuance. International Journal of Electronic Business Management, 10(1), 29.

Igbaria, M., Guimaraes, T., \& Davis, G. B. (1995). Testing the determinants of microcomputer usage via a structural equation model. Journal of Management Information Systems, 11(4), 87-114. http://dx.doi.org/10.1080/07421222.1995.11518061

Igbaria, M., Zinatelli, N., Cragg, P., \& Cavaye, A. L. (1997). Personal computing acceptance factors in small firms: a structural equation model. MIS quarterly, 279-305._http://dx.doi.org/10.2307/249498 
Jih, W. J. K., \& Lee, S. F. (2003). An Exploratory Analysis of Relationships between Cellular Phone Uses' Shopping Motivators and Lifestyle Indicators. Journal of Computer Information Systems, 44(2), 65-73. http://dx.doi.org/10.1080/08874417.2004.11647568

Jung, Y., Perez-Mira, B., \& Wiley-Patton, S. (2009). Consumer adoption of mobile TV: Examining psychological flow and media content. Computers in Human Behavior, 25(1), 123-129. http://dx.doi.org/10.1016/j.chb.2008.07.011

Kalyanam, K., \& Tsay, A. A. (2013). Free riding and conflict in hybrid shopping environments: Implications for retailers, manufacturers, and regulators. The Antitrust Bulletin, 58(1), 19-68. https://doi.org/10.1177/0003603X1305800102

Keller, J., \& Bless, H. (2008). Flow and regulatory compatibility: An experimental approach to the flow model of intrinsic motivation. Personality and Social Psychology Bulletin. 196-209. https://doi.org/10.1177/0146167207310026

Kim, J., Jin Ma, Y., \& Park, J. (2009). Are US consumers ready to adopt mobile technology for fashion goods? An integrated theoretical approach. Journal of Fashion Marketing and Management: An International Journal, 13(2), 215-230. http://dx.doi.org/10.1108/13612020910957725

Kim, Y. K., \& Kang, J. (2001). The effects of ethnicity and product on purchase decision making. Journal of Advertising Research, 41(2), 39-48. http://dx.doi.org/10.2501/JAR-41-2-39-48

Kleijnen, M., De Ruyter, K., \& Wetzels, M. (2007). An assessment of value creation in mobile service delivery and the moderating role of time consciousness. Journal of Retailing, 83(1), 33-46. http://dx.doi.org/10.1016/j.jretai.2006.10.004

Ko, E., Kim, E. Y., \& Lee, E. K. (2009). Modeling consumer adoption of mobile shopping for fashion products in Korea. Psychology \& Marketing, 26(7), 669-687.http://dx.doi.org/10.1002/mar.20294

Lai, J. Y., Debbarma, S., \& Ulhas, K. R. (2012). An empirical study of consumer switching behavior towards mobile shopping: a Push-Pull-Mooring model. International Journal of Mobile Communications, 10(4), 386-404._http://dx.doi.org/10.1504/IJMC.2012.048137

Lee, K. C., Kang, I., \& McKnight, D. H. (2007). Transfer from offline trust to key online perceptions: an empirical study. Engineering Management, IEEE Transactions on, 54(4), 729-741. http://dx.doi.org/10.1109/TEM.2007.906851

Lee, T. (2005). The impact of perceptions of interactivity on customer trust and transaction intentions in mobile commerce. Journal of Electronic Commerce Research, 6(3), 165-180.

Li, M., Dong, Z. Y., \& Chen, X. (2012). Factors influencing consumption experience of mobile commerce: A study from experiential view. Internet Research, 22(2), 120-141. http://dx.doi.org/10.1108/10662241211214539

Li, Z., \& Bai, X. (2011). An empirical study of the influencing factors of user adoption on mobile securities services. Journal of Software, 6(9), 1696-1704._http://dx.doi.org/10.4304/jsw.6.9.1696-1704

Lin, H. F. (2008). Predicting consumer intentions to shop online: An empirical test of competing theories. Electronic Commerce Research and Applications, 6(4), 433-442. http://dx.doi.org/10.1016/j.elerap.2007.02.002.

Liu, C. T., Guo, Y. M., \& Lee, C. H. (2011). The effects of relationship quality and switching barriers on customer loyalty. International Journal of Information Management, 31(1), 71-79. http://dx.doi.org/10.1016/j.ijinfomgt.2010.05.008

Lu, H. P., \& Yu-Jen Su, P. (2009). Factors affecting purchase intention on mobile shopping websites. Internet Research, 19(4), 442-458. http://dx.doi.org/10.1108/10662240910981399

MacInnis, D. J., \& Price, L. L. (1987). The role of imagery in information processing: Review and extensions. Journal of Consumer Research, 473-491._http://dx.doi.org/10.1086/209082

Mallat, N. (2007). Exploring consumer adoption of mobile payments-A qualitative study. The Journal of Strategic Information Systems, 16(4), 413-432._http://dx.doi.org/10.1016/j.jsis.2007.08.001

McIntosh, C. N., Edwards, J. R., \& Antonakis, J. (2014). Reflections on Partial Least Squares Path Modeling. Organizational Research Methods, 17(2), 210-251. https://doi.org/10.1177/1094428114529165

Moon, J. W., \& Kim, Y. G. (2001). Extending the TAM for a World-Wide-Web context. Information \& 
management, 38(4), 217-230._http://dx.doi.org/10.1016/S0378-7206(00)00061-6

Nielsen. (2013). The Mobile Consumer: A Global Snapshot. http://www.nielsen.com/content/dam/corporate/us/en/reports-downloads/2013\%20Reports/Mobileconsumer-Report-2013.pdf

Noble, S. M., Griffith, D. A., \& Adjei, M. T. (2006). Drivers of local merchant loyalty: Understanding the influence of gender and shopping motives. Journal of Retailing, 82(3), 177-188. http://dx.doi.org/10.1016/j.jretai.2006.05.002

Novak, T. P., Hoffman, D. L., \& Yung, Y. F. (2000). Measuring the customer experience in online environments: A structural modeling approach. Marketing Science, 19(1), 22-42. http://dx.doi.org/10.1287/mksc.19.1.22.15184

Okazaki, S. (2005). New perspectives on m-commerce research. Journal of Electronic Commerce Research, 6(3), 160.

Oliver, R. L. (1997). Satisfaction: A behavioral perspective on the customer. McGraw-Hill.

Parasuraman, A., \& Grewal, D. (2000). The impact of technology on the quality-value-loyalty chain: a research agenda. Journal of the Academy of Marketing Science, 28(1), 168-174. https://doi.org/10.1177/0092070300281015

Park, J., Yang, S., \& Lehto, X. (2007). Adoption of mobile technologies for Chinese consumers. Journal of Electronic Commerce Research, 8(3), 196-206.

Pavlou, P. A., \& Gefen, D. (2004). Building effective online marketplaces with institution-based trust. Information Systems Research, 15(1), 37-59. https://doi.org/10.1287/isre.1040.0015

Pew Research Center. 2013. "Yes, Mobile Shoppers Convert at a Higher Rate than Desktop Shoppers." http://www.internetretailer.com/2013/11/07/mobile-shoppers-convert-higher-ratepc-shoppers

Pew Research Center. 2015. Chapter One: A Portrait of Smartphone Ownership http://www.pewinternet.org/2015/04/01/chapter-one-a-portrait-of-smartphone-ownership/

Privette, G. (1983). Peak experience, peak performance, and flow: A comparative analysis of positive human experiences. Journal of Personality and Social Psychology, 45(6), 1361. http://dx.doi.org/10.1037/0022-3514.45.6.1361

Ringle, C. M., Wende, S., and Becker, J. M. (2015). SmartPLS 3. Boenningstedt: SmartPLS GmbH.

Rönkkö M., Evermann J. (2013). A critical examination of common beliefs about partial least squares path modeling. Organizational Research Methods, 16(3), 425-448. https://doi.org/10.1177/1094428112474693

Rönkkö, M., McIntosh, C. N., \& Antonakis, J. (2015). On the adoption of partial least squares in psychological research: Caveat emptor. Personality and Individual Differences, 87, 76-84. http://dx.doi.org/10.1016/j.paid.2015.07.019

Sánchez-Franco, M. J., \& Roldán, J. L. (2005). Web acceptance and usage model: A comparison between goal-directed and experiential web users. Internet Research, 15(1), 21-48. http://dx.doi.org/10.1108/10662240510577059

Scoop Media. 2013. "Smartphone Adoption Driving Mobile Shopping Habits." http://www.scoop.co.nz/stories/BU1304/S00321/smartphone-adoption-driving-mobile-shopping-habits.htm

Shankar, V., \& Balasubramanian, S. (2009). Mobile marketing: a synthesis and prognosis. Journal of Interactive Marketing, 23(2), 118-129._http://dx.doi.org/10.1016/j.intmar.2009.02.002

Shankar, V., Smith, A. K., \& Rangaswamy, A. (2002). Customer satisfaction and loyalty in online and offline environments. International Journal of Research in Marketing, 20(2), 153-175. http://dx.doi.org/10.1016/S0167-8116(03)00016-8

Shankar, V., Venkatesh, A., Hofacker, C., \& Naik, P. (2010). Mobile marketing in the retailing environment: current insights and future research avenues. Journal of Interactive Marketing, 24(2), 111-120. http://dx.doi.org/10.1016/j.intmar.2010.02.006

Sherry Jr, J. F. (1990). Dealers and dealing in a periodic market: informal retailing in ethnographic perspective. Journal of Retailing, 66(2), 174-200. 
Shin, Y. M., Lee, S. C., Shin, B., \& Lee, H. G. (2010). Examining influencing factors of post-adoption usage of mobile internet: Focus on the user perception of supplier-side attributes. Information Systems Frontiers, 12(5), 595-606. http://dx.doi.org/10.1007/s10796-009-9184-x

Siau, K., \& Shen, Z. (2003). Building customer trust in mobile commerce. Communications of the ACM, 46(4), 91-94._http://dx.doi.org/10.1145/641205.641211

Sin, S. S., Nor, K. M., \& Al-Agaga, A. M. (2012). Factors Affecting Malaysian young consumers' online purchase intention in social media websites. Procedia-Social and Behavioral Sciences, 40, 326-333. http://dx.doi.org/10.1016/j.sbspro.2012.03.195

Skadberg, Y. X., \& Kimmel, J. R. (2004). Visitors' flow experience while browsing a Web site: its measurement, contributing factors and consequences. Computers in Human Behavior, 20(3), 403-422. http://dx.doi.org/10.1016/S0747-5632(03)00050-5

Statista. 2016. "Mobile buyer penetration in the United States from 2014 to 2019." http://www.statista.com/statistics/325711/mobile-buyer-penetration-in-the-united-states/

Statista. 2016. "Number of mobile buyers in the United States from 2013 to 2019. http://www.statista.com/statistics/241471/number-of-mobile-buyers-in-the-us/

Statista. 2016. "Statistics and facts about global e-commerce" http://www.statista.com/topics/871/online-shopping/

Tellegen, A., \& Atkinson, G. (1974). Openness to absorbing and self-altering experiences (" absorption"), a trait related to hypnotic susceptibility. Journal of abnormal psychology, 83(3), 268. http://dx.doi.org/10.1037/h0036681

Teo, T. S., Lim, V. K., \& Lai, R. Y. (1999). Intrinsic and extrinsic motivation in Internet usage. Omega, 27(1), 25-37.http://dx.doi.org/10.1016/S0305-0483(98)00028-0

Venkatesh, V. (2000). Determinants of perceived ease of use: Integrating control, intrinsic motivation, and emotion into the technology acceptance model. Information Systems Research, 11(4), 342-365. http://dx.doi.org/10.1287/isre.11.4.342.11872

Venkatesh, V., \& Davis, F. D. (1996). A model of the antecedents of perceived ease of use: Development and test. Decision Sciences, 27(3), 451-481._http://dx.doi.org/10.1111/j.1540-5915.1996.tb00860.x

Venkatesh, V., \& Davis, F. D. (2000). A theoretical extension of the technology acceptance model: Four $\begin{array}{lllll}\text { longitudinal field } & \text { studies. }\end{array}$ http://dx.doi.org/10.1287/mnsc.46.2.186.11926

Venkatesh, V., \& Morris, M. G. (2000). Why don't men ever stop to ask for directions? Gender, social influence, and their role in technology acceptance and usage behavior. MIS Quarterly, 115-139. http://dx.doi.org/10.2307/3250981

Verkasalo, H., López-Nicolás, C., Molina-Castillo, F. J., \& Bouwman, H. (2010). Analysis of users and non-users of smartphone applications. Telematics and Informatics, 27(3), 242-255. http://dx.doi.org/10.1016/j.tele.2009.11.001

Wagner, J. (2011). Anytime/anywhere--playing catch up with the mind of the smartphone consumer. International Journal of Mobile Marketing, 6(1), 28-53.

Wang, Y. S., \& Liao, Y. W. (2008). Understanding individual adoption of mobile booking service: An empirical investigation. Cyber psychology \& Behavior, 11(5), 603-605.http://dx.doi.org/10.1089/cpb.2007.0203

Willaby, H. W., Costa, D. S., Burns, B. D., MacCann, C., \& Roberts, R. D. (2015). Testing complex models with small sample sizes: A historical overview and empirical demonstration of what partial least squares (PLS) can offer differential psychology. Personality and Individual Differences, 84, 73-78. http://dx.doi.org/10.1016/j.paid.2014.09.008

Wu, C. S., Cheng, F. F., Yen, D. C., \& Huang, Y. W. (2011). User acceptance of wireless technology in organizations: A comparison of alternative models. Computer Standards \& Interfaces, 33(1), 50-58. http://dx.doi.org/10.1016/j.csi.2010.03.002

Wu, J. H., \& Wang, S. C. (2005). What drives mobile commerce?: An empirical evaluation of the revised technology acceptance model. Information \& Management, 42(5), $719-729$. http://dx.doi.org/10.1016/j.im.2004.07.001 
Xu, H., Teo, H. H., Tan, B. C., \& Agarwal, R. (2009). The role of push-pull technology in privacy calculus: the case of location-based services. Journal of Management Information Systems, 26(3), 135-174. http://dx.doi.org/10.2753/MIS0742-1222260305

Yang, K. (2010). Determinants of US consumer mobile shopping services adoption: implications for designing mobile shopping services. Journal of Consumer Marketing, 27(3), 262-270. http://dx.doi.org/10.1108/07363761011038338

Yang, K. (2012). Consumer technology traits in determining mobile shopping adoption: An application of the extended theory of planned behavior. Journal of Retailing and Consumer Services, 19(5), 484-491. http://dx.doi.org/10.1016/j.jretconser.2012.06.003

Yang, K., \& Kim, H. Y. (2012). Mobile shopping motivation: an application of multiple discriminant analysis. International Journal of Retail \& Distribution Management, 40(10), 778-789. http://dx.doi.org/10.1108/09590551211263182

Yuan, Y., Archer, N., Connelly, C. E., \& Zheng, W. (2010). Identifying the ideal fit between mobile work and

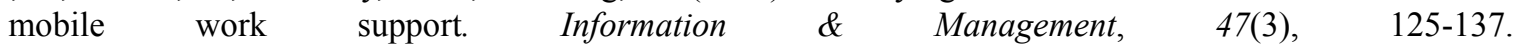
http://dx.doi.org/10.1016/j.im.2009.12.004

Zaman, M., Anandarajan, M., \& Dai, Q. (2010). Experiencing flow with instant messaging and its facilitating role on creative behaviors. Computers in Human Behavior, 26(5), 1009-1018. http://dx.doi.org/10.1016/j.chb.2010.03.001

Zhang, Y., Fang, Y., Wei, K. K., Ramsey, E., McCole, P., \& Chen, H. (2011). Repurchase intention in B2C e-commerce-A relationship quality perspective. Information \& Management, 48(6), 192-200. http://dx.doi.org/10.1016/j.im.2011.05.003

Zhou, T. (2013). An empirical examination of the determinants of mobile purchase. Personal and Ubiquitous Computing, 17(1), 187-195._http://dx.doi.org/10.1007/s00779-011-0485-y

Zhou, T. (2016). Understanding users' switching from online stores to mobile stores. Information Development, 32(1), 60-69._https://doi.org/10.1177/0266666914526605

Zhou, T., \& Lu, Y. (2011). Examining mobile instant messaging user loyalty from the perspectives of network externalities and flow experience. Computers in Human Behavior, 27(2), 883-889. http://dx.doi.org/10.1016/j.chb.2010.11.013

\section{Copyrights}

Copyright for this article is retained by the author(s), with first publication rights granted to the journal.

This is an open-access article distributed under the terms and conditions of the Creative Commons Attribution license (http://creativecommons.org/licenses/by/4.0/). 